\title{
What is a $\mathrm{PhD}$ really worth?
}

\section{An advanced degree doesn't always bring the prospects it once did, says Peter Fiske. But scientists can learn from the travails of those with professional qualifications.}

I the past few months there has been a string of articles ${ }^{1,2}$ in the Western press about the poor career prospects of graduates from professional schools, especially law school. Thanks to a dismal job market, applications to such institutions surged during the recession. Now, a few years later, those applicants are graduating into a career market that is only slightly better - and many have become saddled with debt.

Professional schools are now encountering the graduate-overproduction issues with which $\mathrm{PhD}$ programmes have been wrestling for decades. Entry to law school or medical school once provided a near-certainty of gainful (and often highly lucrative) employment after graduation, but the alumni of these programmes are now struggling to find their first jobs. Many are blaming their graduate schools for promulgating misleading information about their job prospects.

Sound familiar? In the late 1980s, the US National Science Foundation and other groups spread the notion that a wave of retirement was about to sweep through academia, and that the academic job prospects for emerging $\mathrm{PhDs}$ had never been brighter. In fact, the economic assumptions that formed the basis of this prediction were erroneous ${ }^{3}$, and no such wave of retirement took place. In the early 1990s, PhD holders (including myself) spilled into the job market with essentially no guidance on how to find employment outside the ivory tower. The ensuing backlash from young scientists forced the academic establishment to acknowledge that it was producing many more scientific $\mathrm{PhDs}$ than it could accommodate in tenured positions. More importantly, the establishment had to recognize that $\mathrm{PhD}$ scientists could find satisfying and valuable careers outside academia. Although many graduate-student scientists still have their hopes fixed on academic positions, they are now also exploring a range of career options in industry, government and the non-profit sector.

\section{LESSONSFOR LIFE}

The predicament of the current crop of lawand medical-school graduates might give $\mathrm{PhD}$ students an opportunity for Schadenfreude.
But I think that young scientists - and the academic institutions from which they come - can also learn from the dilemma faced by budding lawyers and physicians.

The first lesson is that quality matters. Most of the lamentation from law-school graduates is coming from those who attended lower-ranked programmes. Although there is ample evidence that the current mechanisms for ranking graduate programmes are limited and problematic, there is nevertheless a high correlation between the overall ranking of a programme and the employment outcomes of its alumni. Therefore, prospective students should shop carefully and ask for real data

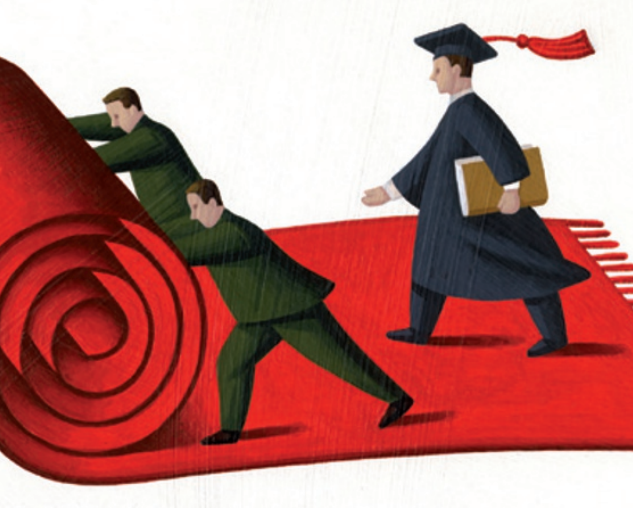

on the career paths of each programme's graduates. In the United States, tools such as the Grad School Guide (http://graduateschool.phds.org) cast light on the actual quality and outcomes of specific graduate courses. And the US National Academy of Sciences has just released its latest ranking of doctoral programmes (http://sites.nationalacademies.org/pga/resdoc/index.htm).

The second lesson is that debt is important - and this is where the situation for science graduates deviates from that of medical and law students. Although graduate students in the sciences essentially sign themselves up for years of penury in university, nearly all US PhD programmes, and many others around the world, provide stipends for their researchers. $\mathrm{PhD}$ students may graduate with few possessions other than a couple of boxes of books and some used Ikea furniture, but at least they do not end up with a huge bill for years of tuition, as law and medical students often do. Frugal science graduate students emerge with a very important life lesson: money does not buy happiness (although it certainly can make misery a lot more comfortable), and living frugally is better than amassing tens of thousands of dollars of debt. Years spent with limited income teach $\mathrm{PhD}$-holding scientists how to be resourceful - and that can be of enormous value throughout a career.

But I believe the most important lesson is that no programme of higher education can guarantee its graduates gainful and lucrative employment. At best, a graduate programme in any discipline can provide its students with key skills, knowledge and abilities. How the graduates apply that learning is up to them.

\section{BROADENED HORIZONS}

That being said, broader training would help graduates' chances. $\mathrm{PhD}$ programmes in the sciences still overemphasize the academic track and actively devalue other career paths. Expanding the $\mathrm{PhD}$ experience and preparing holders of scientific doctorates to be successful in a range of careers would not require a major overhaul of graduate programmes. Focused seminars in areas such as communication, business basics and public policy would go a long way towards strengthening the capabilities of $\mathrm{PhD}$ students and improving their career prospects. Few academic programmes fully appreciate the true potential that $\mathrm{PhD}$ training can confer, or the breadth and depth of value that someone with a $\mathrm{PhD}$ can contribute to the world at large; universities often believe that academia is still the most valuable calling for their graduates.

Graduate students and postdocs are in the best position to organize themselves and insist on such professional education as part of their training. After all, they stand to gain the most. - SEE NEWS FEATURE P.280

Peter Fiske is chief executive of PAX Water Technologies in Richmond, California, and author of Put Your Science to Work (AGU, 2001).

1. Segal, D. 'Is Law School a Losing Game?' The New York Times (8 January 2011). Available at http:// go.nature.com/cf67wp

2. The disposable academic: why doing a PhD is often a waste of time. The Economist (6 December 2010). Available at http://go nature.com/qu7c8z

3. Shapiro, D. T. J. Higher Edu. 72, 532-564 (2001). 